\title{
"Some call Europe, and some call Eneá": on the origins of the Old Icelandic learned prehistory
}

\begin{abstract}
By the $12^{\text {th }}$ century, northern territories were fairly well known in practice, but there was an urgent need to explain the state of this region in written form. In most national narratives, there is an evident tendency to emphasise the similarity of local history with a more significant and more authoritative (Roman or sacred) history (Mortensen 2005). This paper deals with a very specific geographical image-_Europe, or Eneá"-that appears on two "textual maps" by an Icelandic historian of the $13^{\text {th }}$ century, Snorri Sturluson, in his Edda, an Icelandic ars poetica (c. 1220), and in his large compendium of the kings' sagas entitled Heimskringla (c. 1230). The author demonstrates that the toponym Eneá, going back to the ancient hero Aeneas, was formed by Snorri himself as a result of his immersion in the local Icelandic culture and literature, where the Troy story had, by that time, occupied a significant place.
\end{abstract}

Keywords

Knowledge transfer $\bullet$ antiquity $\cdot$ Middle Ages $•$ Old Norse-Icelandic sources - geographical images • toponyms

(C) University of Warsaw - Faculty of Geography and Regional Studies

\author{
Tatjana N. Jackson \\ Institute of World History of the Russian \\ Academy of Sciences, Moscow, \\ Russian Federation \\ e-mail: Tatjana.Jackson@gmail.com \\ Received: 5 October 2018 \\ Accepted: 26 November 2018
}

Introduction

This paper deals with two "textual maps" by an Icelandic historian of the $13^{\text {th }}$ century, Snorri Sturluson, that occur in his Edda, an Icelandic ars poetica (c. 1220), and in his large compendium of Icelandic kings' sagas known under the title of Heimskringla (c. 1230). The main task is to study a very specific geographical image used by Snorri that might have had direct connections with antiquity-"Europe, or Eneá"-and discuss how and why a toponym formed from the name of a legendary ancestor of Rome and the Romans, one of the main defenders of Troy during the Trojan War, Aeneas, the hero of Virgil's Aeneid, could have occupied a place on Snorri Sturluson's mental map.

The "circle of lands"

In the opening chapter of Ynglinga saga, the first saga of Heimskringla, Snorri Sturluson introduces a "textual map" that includes the whole orbis terrarium:

Kringla heimsins, sú er mannfólkit byggvir, er mjǫk vágskorin. Ganga hǫf stór ór útsjánum inn í jǫrðina. Er pat kunnigt, at haf gengr frá Nǫrvasundum ok allt út til Jórsalalands. Af hafinu gengr langr hafsbotn til landnorðrs, er heitir Svartahaf. Sá skilr heimspriðjungana. Heitir fyrir austan Ásíá, en fyrir vestan kalla sumir Európá, en sumir Eneá. En norðan at Svartahafi gengr Svípjóð in mikla eða in kalda. Svípjóð ina miklu kalla sumir menn eigi minni en Serkland it mikla, sumir jafna henni við Bláland it mikla. Inn nørðri hlutr Svípjóðar liggr óbyggðr af frosti ok kulða, svá sem inn syðri hlutr Blálands er auðr af sólarbruna. [...] Ór norðri frá fjǫllum peim, er fyrir útan eru byggð alla, fellr á um Svípjóð, sú er at réttu heitir Tanais. Hon var forðum kọlluð Tanakvísl eđa Vanakvísl. Hon kømr til sjávar inn í Svartahaf. [...] Sú á skilr heimspriðjungana. Heitir fyrir austan Ásiá, en fyrir vestan Európá (ed. Bjarni Ađalbjarnarson 1941).

[The disc of the world that mankind inhabits is very indented with bays. Large bodies of water run from the ocean into the land. It is known that a sea extends from Norvasund (the Straits of Gibraltar) all the way to Jórsalaland (Palestine). From the sea a long gulf called Svartahaf (the Black Sea) extends to the north-east. It divides the world into thirds. To the east is the region called Asia, and the region to the west some call Europe, and some Enea. And from the north to Svartahaf extends Svípjóð in mikla (Sweden the Great) or in kalda (the Cold). Some claim Svípjóð in mikla to be no smaller than Serkland it mikla (Saracen-land the Great, north Africa), others compare it to Bláland it mikla (Blacksland the Great, Africa). The northern part of Svípjóð remains uninhabited because of frost and cold, just as the southern part of Bláland is empty because of the heat of the sun. [...] From the north, from the mountains that are beyond all habitations, flows a river through Svípjóð that is properly called Tanais (Don). It was formerly called Tanakvísl (fork of the Don) or Vanakvísl (fork of the Vanir). It reaches the sea in Svartahaf. [...] This river separates the thirds of the world. The region to the east is called Asia, that to the west, Europe (trans. Finlay \& Faulkes 2011).] 
The Earth in Snorri's "introductory geography" appears in the form of a plane circle surrounded by the ocean and divided into three parts. This image is a reflection of the Christian cosmological concept that prevailed in the Middle Ages, polemicising against the ideas accumulated in the previous epoch as pagan, and refuting the idea of the sphericity of the Earth. The Earth, according to official Christian dogmas, again "became" flat, as in ancient lonian science or in the writings of some Roman geographers whose land descriptions were nothing but the geography of the Earth's disc, or more precisely, of the "circle of lands", orbis terrarum. A threefold division of the Earth became traditional in the medieval European cosmography written in Latin. Such are geographical introductions to a number of medieval chronicles: Historia adversus paganos by Paulus Orosius, $5^{\text {th }}$ century; Historia Brittonum by Nennius, early $9^{\text {th }}$ century; Chronica sive Historia de duabus civitatibus by Otto Frisingensis, the first half of the $12^{\text {th }}$ century. In Iceland, we find this idea in two texts by Snorri Sturluson and in the opening lines of several geographical treatises. Thus, in Landalýsing II ("Description of the Earth II"), AM $7644^{\circ}$, early 14 $4^{\text {th }}$ century, the Earth is described as kringla heimsins divided into the same three parts:

Í upphafi persa litla annálabæklíngs skulo vèr skrifa nokkut litið af heimskringlunni... ok vèr höfum fundit í bókum skilríkum eđr annálum fyrri manna, ok svá hefr. Röksamlig skipan fornrar vizku hefir svá ok heldr, at viðerni heimsbygparinnar er sundrskipt í prjá hluta: heitir einn priðjúngr Asía, ij Europa, iij Affrica (Melnikova 1986, p. 86).

[At the beginning of this little book of annals, we must write a little about the disc of the world... and we have found [all this] in reliable books or annals of ancient people, and it begins like this. Ancient wisdom established a reasonable order, according to which the expanses of the inhabited land are divided into three parts: one third is called Asia, the second is Europe, the third is Africa.]

For the Christian geography of the Middle Ages, a threepart division of the oecumene was not only a development of the ancient view, but also an illustration of the biblical teaching that after the flood all the land was divided between three sons of Noah (Simek 1996). In the Icelandic geographical treatise Fra pui huar huerr Noa sona bygđi heiminn ("How the earth was overspread of all the sons of Noah"), AM 544, $4^{\circ}$, early $14^{\text {th }}$ century, it is written:

Sidan skipti Noe heime med sonum sinum i pria hluti ok gaf nafn öllum hlutum i heiminum, peim sem adr voro önefndir, hann kalladi einn hlut heims Asiam, enn annan Affrikam, enn pridia Eyropam (Melnikova 1986, p. 133).

[Then Noah divided the world into three parts between his sons and gave the names to each part in the world that had no name before. He called one part of the world Asia, the other Africa, and the third Europe.]

Surprisingly, it was well known in medieval Iceland that the earth was spherical. We can judge the prevalence of this knowledge on the basis of the Old Icelandic translation of Elucidarius by Honorius Augustodunensis, on the Second Astronomical Treaty, on Konungs skuggsjá ("The Royal Mirror"), a didactic work written in Norway in the late $13^{\text {th }}$ century, and a number of other works (Faulkes 1978-79, p. 23).
The Tanais

Coming back to Snorri's "textual map", it is worth paying attention to his description of the river Tanais (Don). In his text, the river flows through Svípjóð hin mikla from the mountains in the north that are beyond all habitations, and separates the thirds of the world. It is in this capacity (as a border between Europe and Asia) and under this name (Tanais) that the river is known in ancient and medieval geography and cartography (depicted even on most schematic maps).

In Old-Norse literature, along with Snorri Sturluson's Ynglinga saga, the river is mentioned in a list of rivers dated, according to the oldest manuscript, to the early $14^{\text {th }}$ century, that laconically states the following: "Tanais heitír a. er skilr Europa fra Asia" (Melnikova 1986, p. 152) ["Tanais is the name of a river which separates Europe from Asia"], and in a translation of the Bible into Old Norse called Stjórn, carried out in the late $13^{\text {th }}$ to early $14^{\text {th }}$ centuries: "Europa hefz upp ok tekr til af einni mikils hattar ok frægri aa Tanays" (Melnikova 1986, p. 143) [“Europe begins at the big and famous river Tanais"], the compiler of which had, no doubt, borrowed this description from the Etymologies by Isidore of Seville (c. 560-636).

\section{Scythia}

Snorri's Svípjóð in mikla ("Sweden the Great") that the Tanais flows through resembles ancient Scythia. Old NorseIcelandic sources of the $12^{\text {th }}$ through the $14^{\text {th }}$ centuries include numerous mentions of Scythia (Scitia, Cithia). They are nothing but borrowings from ancient and early medieval writers Augustine (354-430), Gregory the Great (c. 540-604), Isidorus Hispalensis (c. 560-636), Honorius of Autun (the first half of the $12^{\text {th }}$ century), Peter Comestor (died in 1178 or 1198), Vincent of Beauvais (1190-1264). In geographical treatises and religious literature (Stjórn and some Apostles' sagas), as well as in Alexanders saga (a prose translation of Alexandreis), Scythia is not merely included in the lists of lands in different parts of the world, but is always accompanied by an explanation: "Scitia, pat er nu Svipjod hin mikla" ["Scythia, that is now Sweden the Great"], or "Cithia, pat kollvm uer Suipiod hinu myclu" ["Scythia that we call now Sweden the Great"]. Generally, we encounter such explanatory constructions in Icelandic texts when a "bookish" word of a non-Icelandic origin is used, but Svípjóđ in mikla is not a local name, but a part of the gelehrte Urgeschichte, in terms of Andreas Heusler (1908). Its earliest record occurs in Skojldunga saga (composed between 1180-1200), in a legend of the settlement of Scandinavia by emigrants from Asia, according to which the ancestors of Swedish and Norwegian kings were pagan gods headed by Óðinn, the supreme god of the AEsir. This legend goes back to Ari the Wise (early $12^{\text {th }}$ century) and is widely spread in Old Icelandic sources. Walter Baetke believes that Skjoldunga saga connects Svípjóð in mikla with Scythia Magna (Baetke 1973, p. 218), which is indicated at least by the fact that it is placed "to the north of the Maeotian swamps" ["Norden for palude Moeotide"] (ed. Bjarni Guðnason 1982, p. 4). Snorri Sturluson has produced his own variant of this legend of origin, giving "the historical, euhemeristic treatment of the ÆEsir" both in the Prologue to his Edda and in the Ynglinga saga (Faulkes 1983, p. 284). His Svípjóð in mikla is a very weak echo of some ancient knowledge, but mostly a result of his intellectual efforts.

\section{The Riphean Mountains}

According to Snorri, the Tanais river flows through Svípjóð in mikla from "the mountains in the north that are beyond all habitations", but he does not dare give them the name of the Riphean Mountains. As time progressed, as the new territories were developed, the boundary dividing the world known to the Scandinavians and the mysterious space inhabited by 
supernatural and fantastic creatures gradually moved further north and northeast. The northern extremity of Norway, the areas of the Saami, as well as the ocean coast, became more and more well-known from the stories of eyewitnesses who had visited them or sailed along the shore, and therefore there was no room left on the mental map for the Riphean mountains lying beyond all inhabited lands in the north by the ocean. As a result, the Riphean mountains are mentioned only once in the works of Old Norse literature, namely, in a small geographical text dedicated to climatic zones, and several authors, like Snorri, tell of the nameless mountains in the far north from which the river Tanais, separating Europe and Asia, was flowing.

\section{Zonality}

Finally, Snorri's geographical description contains some vague knowledge of the ancient concept of latitudinal climatic and natural zoning. Having written that "the northern part of Svípjóð remains uninhabited because of frost and cold, just as the southern part of Bláland is empty because of the heat of the sun", Snorri thus made it clear that Svípjóð in mikla extends so far north of the Black Sea that it comes outside the inhabited zone and partially enters the northern uninhabited zone, while Blaland it mikla (Africa) enters partly into the equatorial hot uninhabited zone.

\section{A text and a map}

Snorri's descriptive map combines at least three methods of presenting the oecumene that scholars observe in medieval geographic maps: a principle of T-O maps, according to which, Asia, Europe and Africa are surrounded by the ocean and are separated from one another by the Tanais (Don), the Nile and the Mediterranean Sea; a schematic depiction of the world circle indented with the Ocean gulfs; contrasting the northern and southern extremities of the known world, with five climatic zones, the utmost northern and southern being uninhabited for reasons of either cold or heat. It's really tempting (from the position of a modern man) to assume that Snorri, while creating his geographical fragments, relied on a map, since his description is extremely "cartographic". However, we can neither prove, nor completely exclude this.

We only know that Snorri had been brought up by the most powerful chieftain in the country, Jón Loftsson, in his estate Oddi in the south of Iceland, noted both for its school and for the scholarship of its inhabitants. In 1181 Jón Loftsson was forced to offer to foster the infant Snorri. Thus the boy got the opportunity to grow up at one of the main centres of learning in Iceland. As a result, Snorri "received a comprehensive education in the secular spheres required by a young man of chieftainly class aspiring to get on in the world as a poet and a politician: law, poetry, genealogy, cosmology, mythology, and the art of storytelling" (Gísli Sigurðsson 2018, p. 295). We have no information as to what books there were in Oddi, but it's easy to imagine that Latin books with maps (or their copies) were being brought there. As Anthony Faulkes states, "many pieces of classical geography had been translated into Icelandic in the twelfth century, though it is unnecessary to suppose that Snorri had read any of these translations himself" (Faulkes 1993).

Snorri's geography is, no doubt, influenced by contemporary encyclopaedic knowledge: the ocean-girdled orbis tripartitus, climatic zones, etc. However, there is still doubt among scholars, whether Snorri knew Latin or not. As is emphasised in scholarly literature, "there are no quotations or verbal correspondences that can be pointed to indicate precisely what texts were used as sources". In this case the most likely solution would be to believe that Snorri's knowledge in this field was gained orally, "from those people who had read Latin works - either formally in a school", or informally through contacts with learned men, such as Styrmir Kárason inn fróđi who for a time was Snorri's secretary or collaborator at Reykjaholt (Faulkes 1993; Klingenberg 1992). Geographical information could be easily obtained from looking at those maps or diagrams that existed in many medieval manuscripts, and not as a result of reading an accompanying Latin text (Simek 1990).

\section{Europe or Eneá}

Still, there is a place-name that occurs neither in Scandinavian, nor in foreign sources, but is used only by Snorri Sturluson, and is presented as an alternative name for Europe: Európá eđa Eneá. As a rule, the name Europe is explained in Old Norse texts in a different way. One explanation-after a man whose name was Eurofs-occurs in the geographical treatise Landalýsing II. The other one-after Europa, the daughter of Agenor, king of Libia-occurs in Stjórn, and is also borrowed from Isidore's Etymologies.

It is considered that the place-name Eneá is formed based on the name of a legendary ancestor of Rome and the Romans, one of the main defenders of Troy during the Trojan War, Aeneas, the hero of Virgil's Aeneid. Andreas Heusler expresses surprise at the fact that, although there is not a word in Snorri's texts referring to Aeneas or the Trojan time in general, Snorri derives from him the name of Europe (though even in Italy nothing is named after him). According to Heusler, there might be some error here (Heusler 1908, p. 51). Bjarni Aðalbjarnarson, however, believes that Europe, in the eyes of Snorri, does indeed, bear the name of Aeneas because the European nations, the Romans and the Britons, traced themselves from him (ed. Bjarni Aðalbjarnarson 1941, p. 9, n. 7).

It is interesting in this connection to note the opinion of Margaret Clunies Ross (1978, p. 155) that some Latin works were known to Snorri, and that he was familiar with certain subjects from the Aeneid through the medium of Historia Regum Britanniae ("History of the Kings of Britain", 1135-1138) by a Celtic historian of the $12^{\text {th }}$ century, Geoffrey of Monmouth. It is not easy to discover traces of the Aeneid in Iceland (Würth 1998, p. 38, $48,56,59,71,82$ ), however, if Breta sogur ("Stories of the Britons") that include the retelling of the Aeneid are rightly attributed to the monk Gunnlaugr (late $12^{\text {th }}$ century), then it is not unreasonable to assume that the intellectual circles at the Benedictine Pingeirar Monastery (the first monastery in Iceland) to which he belonged were at that time familiar with Virgil (Andersson 2003, p. 15). Heinz Klingenberg sees in the use of the name of Aeneas intertextual reference to Vergil's Aeneid admired throughout the entire Middle Ages, widely read, and used for instruction in medieval schools, and considers the "Európá eða Eneá" in the Edda as a keyword for Snorri's learned prehistory which begins in this work with Troy (Klingenberg 1992). Indeed, both Snorri's works open with a geographical description of the inhabited world and a euhemeristic account of the migrations of the $Æ$ Esir out of Asia and into the north of Europe. Snorri links the $\mathcal{E}$ Esir, the Norse gods, to their ancestral home in Asia on pseudo-etymological grounds: he understands the ÆEsir (singular Ás) as Asiamenn ("people from Asia"). Furthermore, according to the Edda, Óðinn and his people set off on their trip from Asia to Europe from Troy, which positively indicates that, in Snorri's "learned prehistory" Troy and its heroes occupied a very important place.

\section{The Trojan story}

Dares Phrygius's Latin translation (done between the $4^{\text {th }}$ and $6^{\text {th }}$ centuries) of a Greek work (very likely, written in the $1^{\text {st }}$ century AD) entitled De excidio Troiae historia ("The History of the Destruction of Troy") was, no doubt, the most popular work about the fall of Troy in the Middle Ages. Most countries of medieval 
Europe used this concise work to retell the Trojan story. The Old Norse Trójumanna saga ("The saga of the Trojans") is not an exception. It is based on Dares's translation and its author often refers to meistar(i) Dares. The saga has reached our time in more than a dozen manuscripts, so the likelihood of its widespread fame in medieval Iceland is also quite high. All manuscripts of this saga date to not earlier than the $14^{\text {th }}$ century. Still, the story of the Trojan War must have come quite early to Northern Europe. As can be deduced from another pseudo-history, the Veraldar saga ("The World's Saga"), the original version of which is thought to have been written between 1152-1190, a Latin version of the story must have been known in Iceland, and probably in Norway too, at the end of the $12^{\text {th }}$ century. (Würth 2005) The abovementioned Breta sögur could be still another source of information for Snorri on the Trojan War.

\section{Final remarks}

To sum up, Snorri's descriptive map, although it has some kind of antique parallels, is in reality a product of the Middle Ages. Encyclopaedic medieval knowledge could enter through the books, but also through the mediation of better-educated people from Snorri's entourage. Credit for the appearance of the place-name Eneá as a synonym for Europe should go entirely to Snorri himself. His acquaintance with the ancient hero Aeneas is a consequence of his immersion in the local Icelandic culture and literature, where the Troy story occupied a significant place by the end of the $12^{\text {th }}$ century. The idea behind his identification of Europe and Eneá, as it seems to me, is worth searching within the limits of his "learned prehistory": the Trojan hero Aeneas had survived the Trojan War and went on to achieve "great deeds", he left Asia, travelled extensively and came to Europe, just like the AEsir came from Asia to the European North. Thus, this place-name was invented by Snorri to identify Europe with an eponymous founder and to complement the Edda Prologue's theme of the Trojan origins.

\section{Acknowledgements}

I would like to acknowledge the financial support of the RFBR (Russian Foundation for Basic Research), project Nr. 1809-00486.

\section{References}

Andersson, ThM 2003, 'Introduction', in 'The Saga of Olaf Tryggvason' by Oddr Snorrason, trans. ThM Andersson, Cornell University Press, Ithaca \& London, pp. 1-27

Baetke, W 1973, 'Die Götterlehre der Snorra-Edda' ['The Mythology of Snorri's Edda], in Baetke, W, Kleine Schriften, Hermann Böhlaus Nf., Weimar, pp. 216-224

Bjarni Aðalbjarnarson (ed.) 1941, Snorri Sturluson, Heimskringla 1 (Íslenzk fornrit 26), Hið íslenzka fornritafélag, Reykjavík

Bjarni Guðnason (ed.) 1982, Skjǫ/dunga saga, in Danakonunga sogur (Íslenzk fornrit 35), Hið íslenzka fornritafélag, Reykjavík, pp. 3-38

Clunies Ross, M 1978, 'The Myth of Gefjon and Gylfi and Its Function in Snorra Edda and Heimskringla', Arkiv för nordisk filologi, vol. 93, pp. 149-165

Faulkes, A 1978-79, 'Descent from the gods', Mediaeval Scandinavia, vol. 11, pp. 92-125

Faulkes, A 1983, 'Pagan sympathy: attitudes to heathendom in the Prologue to Snorra Edda', in Edda: A Collection of Essays, ed. RJ Glendinning \& H Bessason, University of Manitoba Press, Manitoba, pp. 283-316

Faulkes, A 1993, 'The sources of Skáldskaparmál: Snorri's intellectual background', in Snorri Sturluson. Kolloquium anläßlich der 750. Wiederrkehr seines Todestages, ed. A Wolf, pp. 59-76

Finlay A \& Faulkes A (trans.) 2011, Snorri Sturluson, Heimskringla 1: The Beginnings to Óláfr Tryggvason, Viking Society for Northern Research, London

Gísli Sigurðsson 2018, 'Snorri Sturluson and the Best of Both Worlds', in Snorri Sturluson and Reykholt: The Author and Magnate, his Life, Works and Environment at Reykholt in Iceland, eds Guðrún Sveinbiarnardóttir \& Helgi Porláksson, Museum Tusculanum Press, Copenhagen, pp. 33-78

Heusler, A 1908, Die gelehrte Urgeschichte im altisländischen Schrifttum [The Learned Prehistory in Old Icelandic Literature], Verlag der Königlichen Akademie der Wissenschaften, Berlin

Klingenberg, H 1992, 'Trór Pórr (Thor) wie Trōs Aeneas: Snorra Edda Prolog, Vergil-Rezeption und Altisländische Gelehrte Urgeschichte' [Trór pórr (Thor) as Trōs Aeneas: The Prologue of Snorri's Edda, Vergil-Reception and the Old Icelandic Prehistory], Alvíssmál, vol. 1, pp. 17-54

Melnikova EA 1986, Drevneskandinavskiye geograficheskiye sochineniya. Teksty, perevod, kommentariy [Old
Scandinavian Geographic Treatises. Texts, Translations, Comments], Nauka, Moscow

Mortensen LB 2005, 'The Language of Geographical Description in Twelfth-Century Scandinavian Latin', Filologia mediolatina, vol. 12, pp. 103-121

Simek, R 1990, Altnordische Kosmographie: Studien und Quellen zu Weltbild und Weltbeschreibung in Norwegen und Island vom 12. bis zum 14. Jahrhundert [Old Norse Cosmography: Studies and Sources to World Picture and world Description in Norway and Iceland from the $12^{\text {th }}$ to the $14^{\text {th }}$ century], Walter de Gruyter, Berlin

Simek, R 1996, Heaven and Earth in the Middle Ages: The Physical World before Columbus, The Boydell Press, Woodbridge

Würth, S 1998, 'Die Antikenroman in den isländischen Literatur des Mittelalters: Eine Untersuchung zur Übersetzung und Rezeption lateinischer Literatur im Norden' ['Ancient Novel in Icelandic Literature of the Middle Ages: A Study of Translation and Reception of Latin Literature in the North'], Beiträge zur nordischen Philologie [Papers in Old Norse Philology], vol. 26

Würth, S 2005, 'Historiography and Pseudo-History', in A Companion to Old Norse-Icelandic Literature and Culture, ed. R McTurk, Blackwell Publishing, Oxford, pp. 155-172 